\title{
The Research and Design of the Curriculum Sharing Platform in the Local Application-Oriented Universities
}

\author{
Zhu Peiping \\ Department of physical science and technology \\ Kunming University \\ Kunming, China, 650214 \\ Email: 3267002772@qq.com
}

\begin{abstract}
This paper expounds the connotation of the professional group curriculum sharing platform and the necessity of building the platform. The platform provides an effective way to achieve resource sharing, and provides a good condition for students to learn and develop. The paper puts forward the model of building a professional group curriculum sharing platform and its management measures, which provides a new idea and method for the teaching reform in Local applied universities. Education authorities, schools and platform builders to work together, the platform can get better construction and maintenance.
\end{abstract}

Keywords-Professional group, curriculum sharing platform, model, research

\section{INTRODUCTION}

In recent years, MOOC and other new online open courses in rapid rise in the world. It expands the teaching time and space, enlarges the benefit of high quality educational resources, and brings new opportunities and challenges to the teaching reform and development of higher education. Opinions of the Ministry of education on strengthening the application and management of the construction of online open courses in Colleges and Universities: The Ministry of education encourages the construction of online open courses or courses of different teaching needs and different learning needs by means of collaborative innovation and integrated innovation. In order to improve the quality of education and teaching, universities should promote the deep integration of information technology and education, promote the application and sharing of quality educational resources, and innovate the sharing and application mode of school and interschool courses. ${ }^{[2]}$ In order to strengthen the cooperation and resource sharing of local Application-Oriented universities, this paper puts forward the concept of the construction of professional group curriculum sharing platform.

\section{The ProfESSIONAL GROUP CURRICULUM SHARING PLATFORM}

Professional group is defined by a number of professional and technical bases of identical or closely related, with professional basic knowledge and skills of the common requirements, corresponding to an industry or service areas of the job group. It is composed of a number of professional clusters. Local applied universities according to the local economic and social development level, their own conditions and professional development and other factors, the relevant professional technical field or discipline based close to form a set of professional group. Professional groups in the professional not only can be the same major categories in the professional, but also can be a major category of different professional. ${ }^{[2]}$

Professional groups will exist in the professional must have to learn the professional basic courses or professional core courses. These services in a number of professional courses, is proposed to build a professional group of courses in this paper. These courses are placed on a network platform to provide sharing for teachers and students. There are three characteristics of the professional group curriculum sharing platform: first, Sharing. In general, the teaching system of teaching staff, laboratory equipment and practice teaching system of this kind of course is consistent. These resources are shared among universities. ${ }^{[3]}$ Second, Skills. The kind of course is similar to the professional training target with different talents. According to different majors, those courses should focus on the following aspects, such as teaching focus and content selection, teaching materials preparation and selection, teaching methods and so on.

\section{PROBLEMS IN CURRICULUM CONSTRUCTION OF THE LOCAL APPLICATION-ORIENTED UNIVERSITIES}

At present, there are some problems in the teaching management of some local universities, such as curriculum construction is adopted subject courses, so it is not suitable for training applied talents. The curriculum emphasis on theoretical teaching and neglects the practical teaching. The curriculum emphasizes overly the completion of the subject system, resulting in duplication of teaching content.In some schools, there are not enough teachers and the standards and levels of curriculum development are uneven. ${ }^{[4]}$ In the curriculum construction, the information technology teaching methods have not been fully utilized, and so on. In view of these problems, the author puts forward the construction of the professional group curriculum sharing platform to solve the problems.

In this paper, the research result of Kunming University Fund for Scientific Research topics (ID: XJZD1601) for 2016 years. 


\section{CURRICULUM SHARING PlATFORM}

\section{A. To improve the efficiency of the input and output of the} universities

The construction of professional group curriculum sharing platform should focus on the connotation construction of professional talents training. On the basis of the professional core skills training, the development and construction of the course and experimental training, this can focus on the construction of high quality, high level, high quality resources to share the high level courses and experimental training base. This can not only achieve high-quality personnel training objectives, but also reduce the cost of teaching practice.

\section{B. To conducive to the formation of the teachers' team}

Local Application-Oriented universities to carry out the construction of professional group platform, it is necessary to set up a curriculum leader in charge, double division type teachers as the main body of the teacher team. ${ }^{[5]}$ The members of the teachers' team come from a wide range of sources. Through the development, design and construction of the platform, a good team of teachers is gradually formed.

\section{To strengthening the connotation construction of local Application-Oriented universities}

The construction of the sharing platform of professional group courses will help to promote the construction of teaching materials, which is helpful to improve the mode of curriculum evaluation. It makes the curriculum construction and professional construction more conducive to the cultivation of high-quality applied talents.

\section{The Measures to SOlve the Curriculum \\ CONSTRUCTION AND RESOURCE SHARING OF LOCAL APPLICATION-ORIENTED UNIVERSITIES}

\section{A. Reconstruction of professional group curriculum}

Local universities can reconstruct the existing curriculum. The specific approach is: the universities should use active teaching methods, implement the student center and the ability standard principle, from the curriculum design and teaching, classroom management, evaluation, complete process records and other aspects, to carry out a comprehensive transformation of the concept of network sharing, gradually formed the shared curriculum design standard. It is conducive to play the advantages of information technology, in order to achieve rapid development in accordance with the standard course, according to the group of efficient sharing of courses, according to the purpose of access to open information.

\section{B. Advantages of constructing the professional group curriculum sharing platform}

1) To improve teaching quality

Local applied universities of construction into the curriculum should adopt the unified teaching standards of adaptable skills training, the teaching material resources suitable for the skills demand, the network characteristics of the applied talents, standardize the students' learning process and evaluation methods, so as to enhance the teaching quality. ${ }^{[6]}$ At the same time, universities should train and form a team of teaching masters, to create a guarantee for the sustainable development of the platform.

\section{2) To integrate and optimize of resources}

Through the construction of the professional group curriculum platform, the local applied universities integrate, develop and apply the high quality teaching materials of different levels, different regions, different management institutions and different characteristic enterprises and make them fully reflected in the network curriculum and teaching activities. In order to solve the problem of quality local teaching materials into the classroom, enhance the full use of high-quality resources.

\section{3) To improve social participation}

The application of the professional group curriculum sharing platform can make parents, enterprises and social quality resources pooled and participate in the evaluation of local applied oriented universities teaching effect, can improve the teaching evaluation of fairness and openness. At the same time, the platform also can better reflect the educational characteristics of school-enterprise cooperation, and enhance the relevance and adaptability of student employment.

4) To be model of professional group curriculum platform

This article advocates the use of modern information technology, the method and the construction of specialty group channels, resources, process and evaluation into the network sharing platform, in order to promote professional group curriculum construction, so that professional groups to share quality courses, improve vocational quality and level of teaching .

\section{To construct the model of professional group curriculum} sharing platform

\begin{tabular}{|c|c|c|c|}
\hline $\begin{array}{c}\text { Teacher } \\
\text { teaching } \\
\text { management } \\
\text { module }\end{array}$ & $\begin{array}{c}\text { Learning } \\
\text { process } \\
\text { management } \\
\text { module }\end{array}$ & $\begin{array}{c}\text { Enterprise } \\
\text { resource } \\
\text { management } \\
\text { module }\end{array}$ & $\begin{array}{c}\text { Teaching } \\
\text { evaluation } \\
\text { management } \\
\text { module }\end{array}$ \\
\hline \multicolumn{4}{|c|}{ MOODLE } \\
\hline $\begin{array}{c}\text { My SQL } \\
\text { Database server }\end{array}$ & $\begin{array}{c}\text { Apache } \\
\text { Web server }\end{array}$ & Scripting lan & $\begin{array}{l}\mathrm{HP} \\
\text { age development }\end{array}$ \\
\hline \multicolumn{4}{|c|}{ AMP Base platform } \\
\hline
\end{tabular}

Fig. 1. Professional group curriculum sharing platform

The basic modules and functions of the sharing platform

1) Teacher teaching management module

This module shows the requirements of the professional group teaching market research reports, talent demand report, job requirements, and learning content with this combination of curriculum standards, teaching syllabus and teaching schedule content, activities, strategies, resources, interaction and evaluation. The teaching arrangement is accordance with the progress of teaching to guide students to learn, it includes courseware, animation, micro courses. This module arranges 
the teaching tasks through the network learning community. This module through the online group to participate in the discussion, presentation and evaluation, record the learning traces of the learners, the realization of the process of management and evaluation.

According to the spatial and temporal distribution of the professional group of teachers, set up their online teaching and research functions. Through the planning of the task arrangement, the professional group of teachers to mobilize completes the language learning materials and video class learning resources.

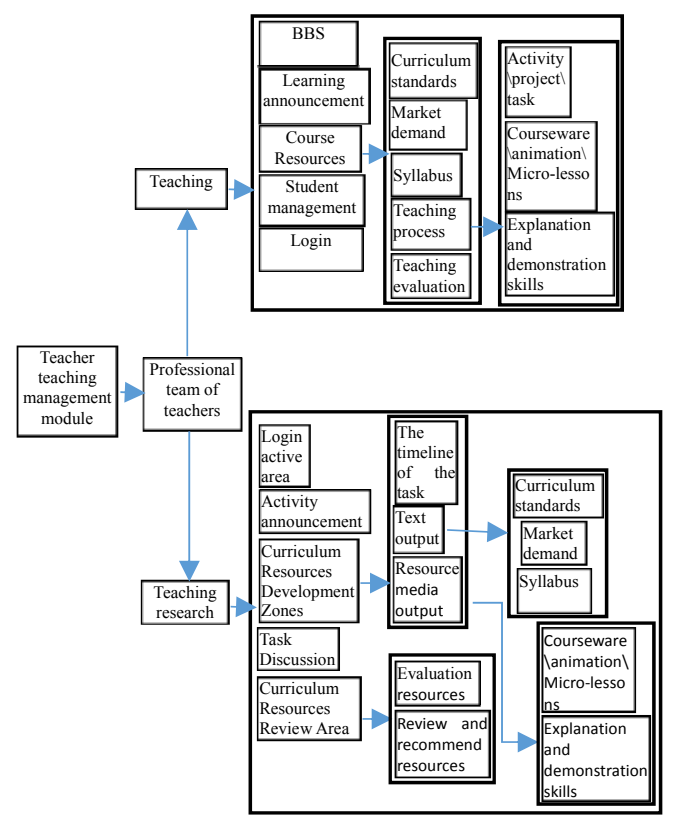

Fig. 2. Teacher teaching management module

\section{2) Learning process management module}

The module records students in individual learning, group activities and the whole class learning process traces, such as participate in the discussion, submit work, show results, etc. By recording the data of learning, teachers can analyze the changes of students' learning performance, and guide the students to pay attention to the content and the task, while displaying the results of the students' learning process.

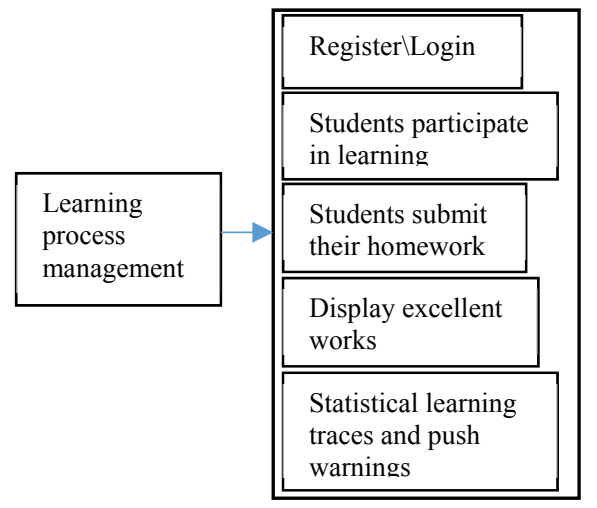

Fig. 3. Learning process management
3) Enterprise resource management module

According to the characteristics of local applied universities, the professional group curriculum sharing platform will introduce the enterprise into the curriculum. Through the analysis of enterprise job skills requirements, guide teachers to the teaching target and characteristics.

According to the characteristics of network teaching, teachers carry out the learning process evaluation and learning traces management for students, recommend outstanding students for the enterprise, in order to stimulate students' learning initiative and enthusiasm, at the same time, they can also try to solve the problem of learning burnout of students.

Enterprises can also be registered to enter the system to view the learning process and performance changes to their counterparts in the professional students, aiming at seed students in advance to improve the effectiveness of enterprise recruitment.

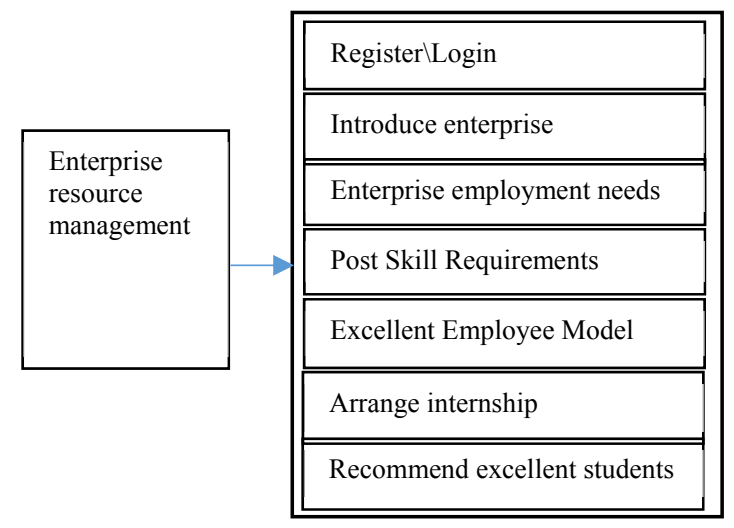

Fig. 4. Enterprise Resource Management

\section{4) Teaching evaluation management module}

This module is used to solve the problems of openness and fairness. Through this platform, the schools not only allows experts to participate in the evaluation of teaching quality in a convenient time and space, but also give students and managers an interface, so that they participate in the assessment or understanding of the assessment process. Finally, according to the comprehensive consideration, the school can recommend excellent courses for more reference and application to other schools.

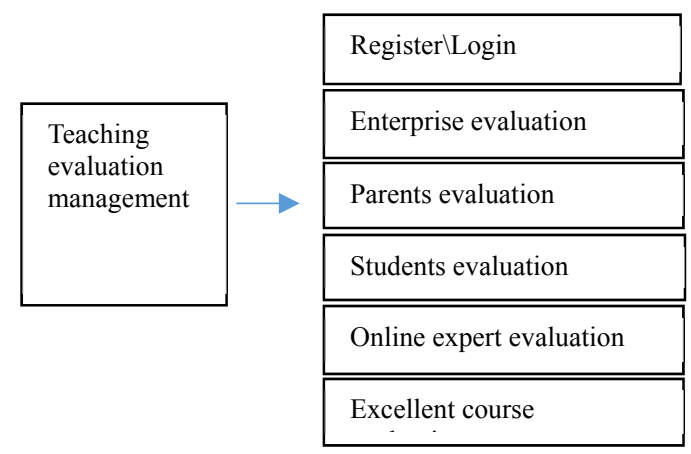

Fig. 5. Teaching evaluation management 


\section{TO STRENGTHEN THE MANAGEMENT OF THE} ProfESSIONAL GROUP CURRICULUM SHARING PLATFORM

\section{A. Education administration should support the construction} of professional group curriculum sharing platform

Local education authorities should support the curriculum sharing platform. Through the use of evaluation and regular inspection, local education authorities should track and monitor and evaluate on the course of online operation and the practical application and teaching effectiveness. The local education authorities should also regulate the network security, content security, data security, operation and service of the course platform.

\section{B. Local universities should undertake the responsibility of curriculum construction and management}

Local applied universities should focus on enhancing teachers' awareness, level and ability of deep integration of information technology and education. The universities should share the platform as an important complement to classroom teaching. According to the actual situation, universities should establish curriculum teaching and learning management, incentive and evaluation mechanisms. Universities should foster a number of oriented correct, the large influence of the network of teaching teachers. ${ }^{[7]}$ Universities as the main responsibility of the course content and teaching activities, they should establish and implement the curriculum construction, quality review, curriculum operation security and effectiveness evaluation system, and constantly improve the quality of the course.

\section{Management group should strength monitoring on the professional group curriculum sharing platform}

The curriculum sharing platform builders to improve the curriculum content of the review system, but also to strengthen the supervision of the teaching process and platform operation, to prevent and prohibit the spread of harmful information, in order to ensure the stability of the platform to run and the security of users and resources. The curriculum sharing platform builders should also effectively assume the main responsibility for curriculum services and data security. Only in this way, can the professional group curriculum sharing platform to play its role.

\section{CONCLUSION}

Constructing the professional group curriculum sharing platform is an effective way to optimize the integration of resources among professionals, so that all kinds of high quality resources can be fully utilized. This integration can be expanded to universities, which can not only optimize the professional structure, strengthen the strength of teachers, but also conducive to the learning and development of students.

\section{REFERENCES}

[1] ZHANG Liping. A Study on the Construction of Platform Courses of Mechanical Specialty Groups__Based on the Practice of Machinery Specialty Group in Nantong Vocational University [J]. Journal of Nantong Vocational University, 2016, 30(1):55-57(In Chinese)

[2] WANG Lixia. Problems of the construction of the curriculum construction in newly-built Local Universities[J], Journal of educational institute of Jilin province, 2014.8:4(In Chinese)

[3] HU Ying, Xia Xiaoping, Cui Shanfeng. The teaching reform and design of professional group platform curriculum $[\mathrm{J}]$. Education and Vocation, 2012.23:12-13(In Chinese)

[4] ZHOU Jinsong. Development of "Platform + Module + Direction" Curriculum System Based on Specialty Cluster in Higher Vocational Schools [J]. Vocational and Technical Education, 2013, 34(8):23-26(In Chinese)

[5] HE Jing. The Effective Path to Professional Group Building in Higher Vocational Colleges__Building a "platform + Module" professional group curriculum system [J]. Journal of Guangdong polytechnic normal university, 2009(1):72-74(In Chinese)

[6] Feng Chong you, Zhang Jinmei. Researches on Work-study Combination Modularized Platform Curriculum of Machinery and Electronic Specialized Group in Vocational Education [J]. Journal of Weifang educational college, 2010, 23(5):84-85(In Chinese)

[7] WU Xiaodong, ZHANG Hairong. Research on the development and implementation system of the platform curriculum for electric power specialty group [J]. China Electric Power Education, 2013, (11):35-36(In Chinese) 